\title{
Proceedings of the Inaugural Meeting of the International Forum for Reactor Aging Management (IFRAM)
}

LJ Bond

DL Brenchley

September 2011

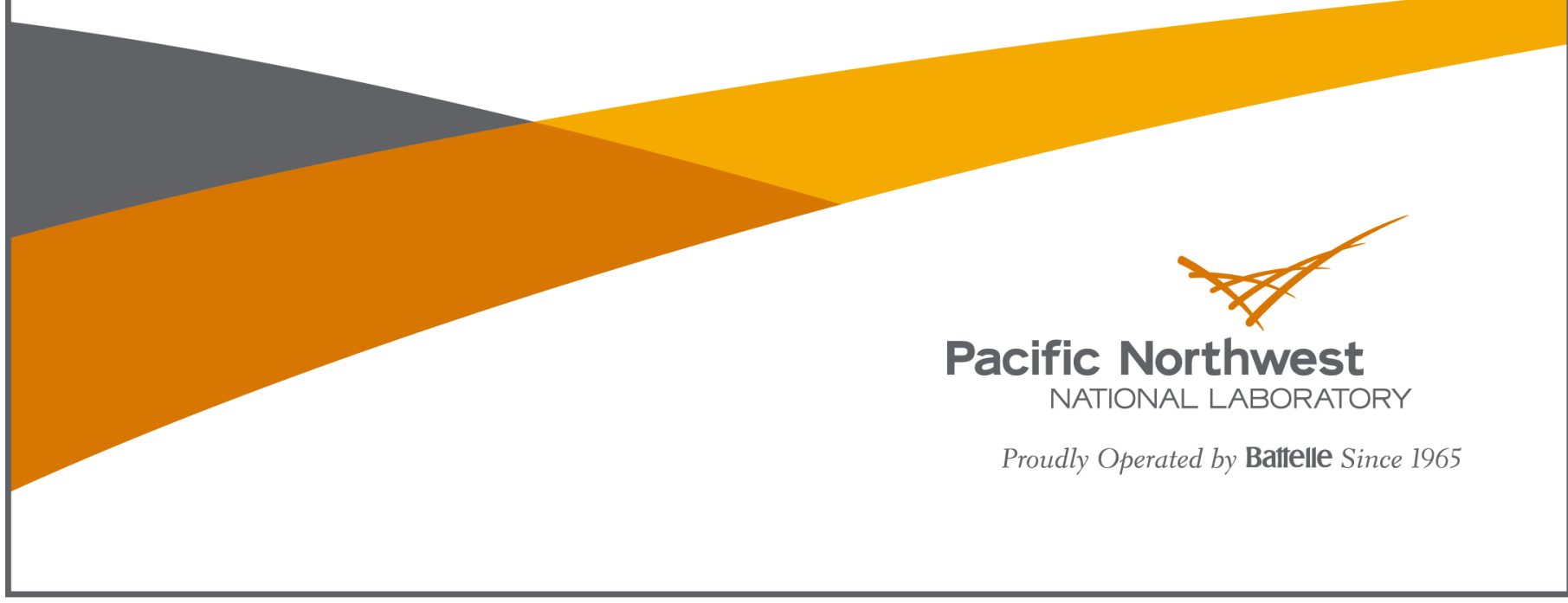




\title{
DISCLAIMER
}

This report was prepared as an account of work sponsored by an agency of the United States Government. Neither the United States Government nor any agency thereof, nor Battelle Memorial Institute, nor any of their employees, makes any warranty, express or implied, or assumes any legal liability or responsibility for the accuracy, completeness, or usefulness of any information, apparatus, product, or process disclosed, or represents that its use would not infringe privately owned rights. Reference herein to any specific commercial product, process, or service by trade name, trademark, manufacturer, or otherwise does not necessarily constitute or imply its endorsement, recommendation, or favoring by the United States Government or any agency thereof, or Battelle Memorial Institute. The views and opinions of authors expressed herein do not necessarily state or reflect those of the United States Government or any agency thereof.

\author{
PACIFIC NORTHWEST NATIONAL LABORATORY \\ operated by \\ BATTELLE \\ for the \\ UNITED STATES DEPARTMENT OF ENERGY \\ under Contract DE-AC05-76RL01830
}

Printed in the United States of America

Available to DOE and DOE contractors from the Office of Scientific and Technical Information,

P.O. Box 62, Oak Ridge, TN 37831-0062;

ph: (865) 576-8401

fax: (865) 576-5728

email: reports@adonis.osti.gov

\author{
Available to the public from the National Technical Information Service, \\ U.S. Department of Commerce, 5285 Port Royal Rd., Springfield, VA 22161 \\ ph: (800) 553-6847 \\ fax: (703) 605-6900 \\ email: orders@ntis.fedworld.gov \\ online ordering: http://www.ntis.gov/ordering.htm
}

This document was printed on recycled paper.

$(9 / 2003)$ 


\title{
Proceedings of the Inaugural Meeting of the International Forum for Reactor Aging Management (IFRAM)
}

\author{
LJ Bond \\ DL Brenchley
}

September 2011

Prepared for

the U.S. Department of Energy

under Contract DE-AC05-76RL01830

Pacific Northwest National Laboratory

Richland, Washington 99352 



\section{Abstract}

In almost all countries with nuclear power plants (NPPs), regulatory authorities and the nuclear industry are looking at some form of extended operating periods. To support life extension activities it is necessary to ensure the continued safety and reliability of system, structures, and components, and the component materials. Internationally, a variety of individual national and international activities have been initiated including Plant Life Management through the International Atomic Energy Agency, Electric Power Research Institute's Long Term Operation program, and various national programs in managing materials degradation and related topics.

The U.S. Nuclear Regulatory Commission (NRC) engaged the international community in workshops in 2005-2006 to identify research needs and to collect information in an expert panel report on Proactive Management of Materials Degradation (PMMD), which was reported in NUREG/CR-6923. These results are also available via an Information Tool on the internet at http://pmmd.pnl.gov. This information builds on the extensive compilations known as the GALL Report (Generic Aging Lessons Learned, NUREG1801, Vols. 1 and 2). Pacific Northwest National Laboratory (PNNL) recently issued a report on the review of various international activities in PMMD (PNNL-17779). There have also been initiatives by Electricite de France, Tokyo Electric Power Company, EPRI, and others to establish a "Materials Aging Institute." Within the materials degradation research community there are also networks and technical meetings focused on some elements of PMMD. In spite of all these efforts, there is currently no forum to bring together these diverse activities and provide coordinated information exchange and prioritization of materials aging management/PMMD topics. It is believed that the International Forum for Reactor Aging Management (IFRAM) would be a good way to achieve this goal and help develop new approaches for ensuring continued safe operation in existing and future nuclear power plants.

To begin addressing this need, NRC has established a Proactive Management of Materials Degradation Program for managing in-service degradation of metallic components in aging NPPs. The NRC is seeking to facilitate the establishment of IFRAM as a network of international experts who would exchange information on operating experience, best practices, and emerging knowledge. These experts would be willing to work jointly and leverage the separate efforts of existing national programs into a unified approach to enable the potential for the safe and economic life extension of NPPs.

A proposal for establishing IFRAM was developed and presented at Engagement workshops in Seoul, Korea (October 2009) and Petten, The Netherlands (May 2010). Participants in both groups demonstrated strong interest in the establishment of IFRAM. Therefore the Global Steering Committee was formed to plan and carry out the start-up of IFRAM in 2011. This group finalized the documents for IFRAM and organized the kick-off meeting. This document records the contents of the inaugural meeting of IFRAM, which was held August 4-5, 2011, at the Cheyenne Mountain Resort in Colorado Springs, Colorado. Representatives from Asia, Europe, and the United States met to share information on reactor aging management and make plans for the future. Professor Tetsuo Shoji was elected chairperson of the Leadership Council. This kick-off event transformed the dream of an international forum into a reality. IFRAM has begun to achieve its mission. 



\section{Summary}

The inaugural meeting of the International Forum for Reactor Aging Management is the fulfillment of a dream to inspire global cooperation in identifying and addressing technical issues in the aging of nuclear power plants (NPPs). In 2008 a proposal was put forth to establish an International Forum to promote cooperation on reactor aging management. The name went through several iterations to become the International Forum for Reactor Aging Management (IFRAM). This name was selected as the "umbrella terminology" for the diverse array of existing programs and activities which deal with extending the safe operating life of NPPs. These include the International Atomic Energy Agency's Plant Life Management, the Electric Power Research Institute's Long Term Operation, the U.S. Department of Energy's Light Water Reactor Sustainability Research and Development (R\&D) Program, the U.S. Nuclear Regulatory Commission's Proactive Management of Materials Degradation, and others. All of these activities address aging management of the materials and systems, structures and components that make up NPPs.

The proposal for establishing IFRAM was presented at Engagement workshops in Seoul, Korea (October 2009) and Petten, The Netherlands (May 2010). Participants in both groups demonstrated strong interest in the establishment of IFRAM. Therefore the Global Steering Committee was formed to plan and carry out the start-up of IFRAM in 2011. This group finalized the documents for IFRAM and organized the kick-off meeting with the following objectives:

1) Affirm the purpose, nature, benefits and working aspects of IFRAM.

2) Hear regional reports on present and future IFRAM activities in Asia, Europe, and the United States.

3) Initiate some technical focus groups to address important reactor aging management issues.

4) Stimulate the development of collaborative efforts to address $R \& D$ on reactor aging management issues.

5) Affirm organization and leadership for the next year.

6) Review calendar of IFRAM-related events and activities.

The meeting was unanimously voted a major success. Everyone participated and stayed for the two days of activities. The main outcomes of the meeting were:

- Fifteen (15) presentations on reactor aging management activities.

- A proposal to establish a focus group on "Technical Issues Related to Plant Life Management."

- A proposal to establish a focus group for "Technologies for Monitoring Aging and Materials Degradation."

- Signing ceremony of IFRAM kick-off meeting participants.

- List of Recommended Collaborative Research Topics. Recommended actions were proposed for the highest priority topics.

- List of ideas that participants want IFRAM to do.

- Election of Professor Tetsuo Shoji as Chairperson of the Leadership Council.

- List of ideas for future IFRAM activities.

The meeting presentations and focus group presentations were put on CDs, sent to all participants, and posted on the IFRAM website: http://ifram.pnnl.gov. 



\section{Acknowledgments}

The authors thank the U.S. Nuclear Regulatory Commission, under JCN V6231, for their support of the planning and conduct of the IFRAM Inaugural Meeting. 



\section{Acronyms and Abbreviations}

$\begin{array}{ll}\text { AMP } & \text { Aging Management Program } \\ \text { AMR } & \text { aging management review } \\ \text { CBM } & \text { condition-based maintenance } \\ \text { DOE } & \text { U.S. Department of Energy } \\ \text { EdF } & \text { Electricitie de France } \\ \text { EPRI } & \text { Electric Power Research Institute } \\ \text { GALL } & \text { Generic Aging Lessons Learned } \\ \text { GSC } & \text { Global Steering Committee } \\ \text { IAEA } & \text { International Atomic Energy Agency } \\ \text { IFRAM } & \text { International Forum for Reactor Aging Management } \\ \text { ISI } & \text { in-service inspection } \\ \text { LTO } & \text { long-term operation } \\ \text { LWRSP } & \text { Light Water Reactor Sustainability Program } \\ \text { MAI } & \text { The Materials Aging Institute } \\ \text { NEA } & \text { Nuclear Energy Agency } \\ \text { NULIFE } & \text { Nuclear Plant Life Prediction } \\ \text { NPP } & \text { nuclear power plant } \\ \text { NRC } & \text { U.S. Nuclear Regulatory Commission } \\ \text { OLMP } & \text { on-line monitoring and prognostics } \\ \text { PLiM } & \text { plant life management } \\ \text { PMMD } & \text { proactive management of materials degradation } \\ \text { PNNL } & \text { Pacific Northwest National Laboratory } \\ \text { PVP } & \text { Pressure Vessels \& Piping } \\ \text { R\&D } & \text { research and development } \\ \text { SRP-LR } & \text { standard review plan for license renewal } \\ \text { SSC } & \text { systems, structures, components } \\ \text { SMiRT } & \text { Structural Mechanics in Reactor Technology } \\ \text { TEPCO } & \text { Tokyo Electric Power Company } \\ & \end{array}$





\section{Contents}

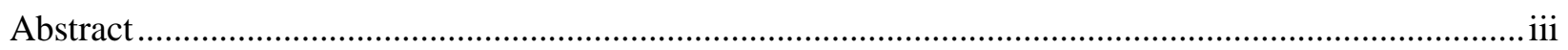



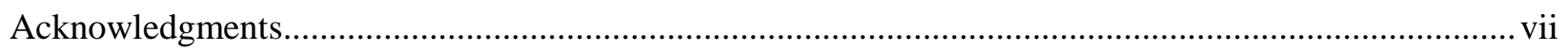





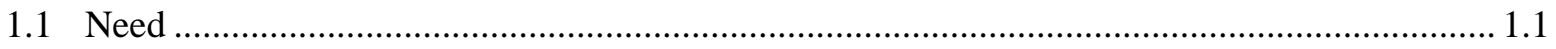

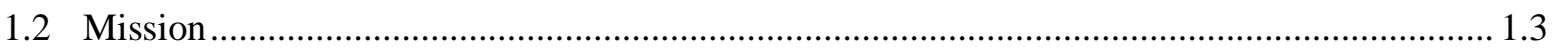

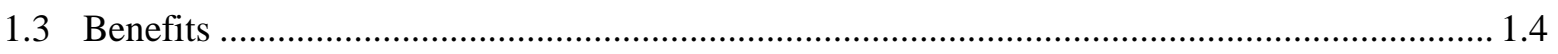

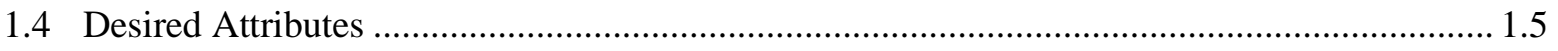

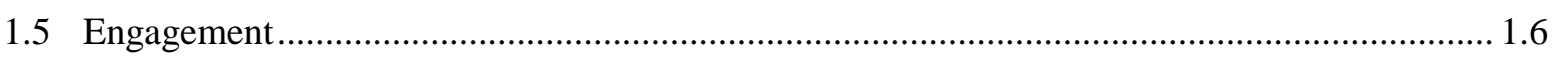

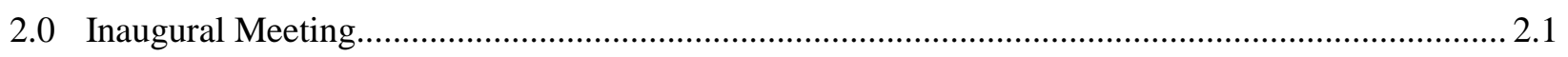

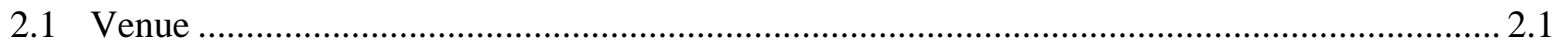

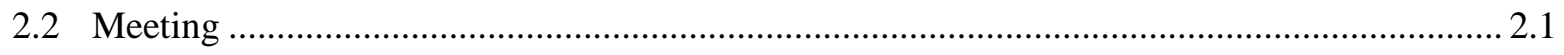



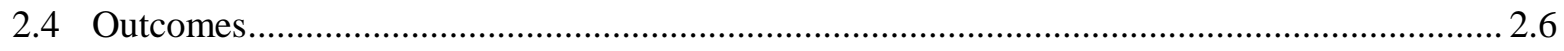

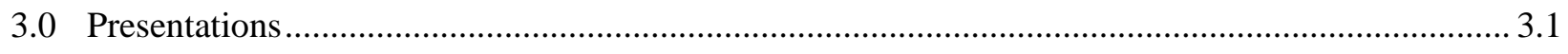



Appendix A - Instructions for Focus Group "Plant Life Extension Guidelines" ................................... A.1

Appendix B - Instructions for Focus Group “On-line Monitoring” .........................................................1

Appendix C - Instructions for Breakout Groups "Collaborative Research Topics in Reactor Aging Management —Post Fukushima" ............................................................................................... 1

Appendix D - Instructions for Brainstorming: Ideas for Future IFRAM Activities............................... D.1 


\section{Tables}

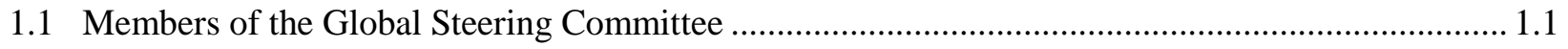

2.1 Participants in IFRAM “Kick-Off” Meeting ....................................................................... 2.5 


\subsection{Vision}

In 2008 a proposal was put forth to establish an International Forum to promote cooperation on reactor aging management. The name went through several iterations to become the International Forum for Reactor Aging Management (IFRAM). This name was selected as the "umbrella terminology" for the diverse array of existing programs and activities which deal with extending the safe operating life of nuclear power plants (NPPs). These include the International Atomic Energy Agency's (IAEA) Plant Life Management (PLiM), the Electric Power Research Institute's (EPRI) Long Term Operation (LTO), the U.S. Department of Energy's (DOE) Light Water Reactor Sustainability Research and Development (R\&D) Program (LWRSP), the U.S. Nuclear Regulatory Commission's (NRC) Proactive Management of Materials Degradation (PMMD), and others. All of these activities address aging management of the materials and systems, structures and components (SSCs) that make up NPPs.

The proposal for establishing IFRAM was presented at Engagement workshops in Seoul, Korea (October 2009) and Petten, The Netherlands (May 2010). Participants in both groups demonstrated strong interest in the establishment of IFRAM. Therefore the Global Steering Committee (GSC) was formed to plan and carry out the start-up of IFRAM in 2011. This group finalized the documents for IFRAM and organized the kick-off meeting. The members of the GSC are listed in Table 1.1.

Table 1.1. Members of the Global Steering Committee

\begin{tabular}{ll}
\hline \multicolumn{1}{c}{ Name } & \multicolumn{1}{c}{ Affiliation } \\
\hline $\begin{array}{l}\text { Bieth, Michel (represented by } \\
\text { Oliver Martin) }\end{array}$ & Joint Research Centre, European Commission \\
Blahoianu, Andrei & Canadian Nuclear Safety Commission \\
Bond, Leonard & Pacific Northwest National Laboratory (Steering Committee Secretariat) \\
Brumovsky, Milan & Nuclear Research Institute Rez \\
Carpenter, C.E. (Gene) & U.S. Nuclear Regulatory Commission \\
Gaertner, John & Electric Power Research Institute \\
Han, En-Hou & Institute of Metal Research, Chinese Academy of Sciences \\
Huerta, Alejandro & Nuclear Energy Agency \\
Hwang, Il Soon & Seoul National University \\
Kain, Vivekanand & Homi Bhabha National Institute, Mumbai Head, Corrosion Science Section \\
Kang, Ki-Sig & International Atomic Energy Agency \\
Lee, Jan van der & Materials Aging Institute \\
Reister, Richard & U.S. Department of Energy \\
Rintamaa, Rauno & NULIFE \\
Shoji, Tetsuo & Tohoku University \\
Tilley, Richard & Electric Power Research Institute \\
\hline
\end{tabular}

\subsection{Need}

Globally there are approximately 440 operating commercial NPPs in 30 countries. These plants, which have an average age greater than 20 years, were licensed to operate for 30 to 40 years. To meet the growing global demand for electricity, particularly to support development, it is projected that about 2,300 GWe of new generating capacity would need to be built over the next 20-30 years. There are currently about 40 new NPPs under construction (all outside the United States) and at least 222 new NPPs 
(including 45 in the United States) that are being considered in 42 nations; 14 of these nations currently do not have domestic commercial nuclear power programs. The costs for these projects are being projected to be significant (up to $\$ 7.5$ billion for a new U.S. 1,000+ MWe plant) and the recent economic downturn has the potential to delay or cancel many of these projects. However, there remains the everincreasing need for reliable supplies of electricity coupled with a growing desire to limit carbon emission and convert to transportation powered by electricity. These factors explain the current interest in extending the service life of existing NPPs.

The majority of U.S. plants are expected to seek 20-year license extensions and 59 extensions have been granted to date (December 2009) by the NRC, with another 18 applications under NRC review, and 15 more announced. The U.S. nuclear industry is now beginning to focus on requesting a second period of extended operations (i.e., from 60 to 80 years) and even potentially additional periods after 80 years.

In almost all countries with NPPs, regulatory authorities and the nuclear industry are looking at some form of extended operating periods. To support life extension activities it is necessary to ensure the continued safety and reliability of SSCs and the component materials. Internationally, a variety of individual national and international activities have been initiated including PLiM through the IAEA, EPRI's LTO program, and various national programs in managing materials degradation and related topics.

The NRC engaged the international community in workshops in 2005-2006 to identify research needs and to collect information in an expert panel report on PMMD, which was reported in NUREG/CR-6923 (Andresen et al. 2007). These results are also available via an Information Tool on the internet at http://pmmd.pnl.gov. This information builds on the extensive compilations known as the Generic Aging Lessons Learned (GALL) Report (NUREG-1801, Vols. 1 and 2; NRC 2005a, b). Pacific Northwest National Laboratory (PNNL) recently issued a report on the review of various international activities in PMMD (PNNL-17779; Bond et al. 2008). There have also been initiatives by Electricite de France (EdF), Tokyo Electric Power Company (TEPCO), EPRI, and others to establish a "Materials Aging Institute." Within the materials degradation research community, there are also networks and technical meetings focused on some elements of PMMD. In spite of all these efforts, there is currently no forum to bring together these diverse activities and provide coordinated information exchange and prioritization of materials aging management/PMMD topics. It is believed that IFRAM would be a good way to achieve this goal and help develop new approaches for ensuring continued safe operation in existing and future nuclear power plants.

To begin addressing this need, NRC has established a Proactive Management of Materials Degradation Program for managing in-service degradation of metallic components in aging NPPs. The NRC is seeking to facilitate the establishment of IFRAM as a network of international experts who would exchange information on operating experience, best practices, and emerging knowledge. These experts would be willing to work jointly and leverage the separate efforts of existing national programs into a unified approach to enable the potential for the safe and economic life extension of NPPs. 


\subsection{Mission}

The mission of IFRAM is to:

- Invite the participation of international experts and organizations knowledgeable in the degradation of nuclear reactor materials;

- Facilitate the exchange and pooling of experience, results and knowledge; and

- Promote cooperation in identifying and addressing technical issues.

A healthy IFRAM requires building strong participation to achieve its mission. IFRAM will provide peer review/identify best practices in the emerging aging management processes to:

- Ensure safe and secure plant life extension,

- Identify regulatory gaps,

- Establish the technical bases for life extension - particularly provide an assessment of the state of the art,

- Identify open questions and issues that require research or other actions, and

- Establish a data base (and library of materials) for naturally and laboratory-aged materials, particularly focused on beyond 40+ years.

IFRAM will facilitate the appropriate exchange of information among those parties and organizations around the world that are presently, or will be, addressing issues related to NPP SSCs aging management. Four objectives support this purpose: (i) cooperating to achieve common objectives, (ii) sharing information/data, (iii) entering into joint research/demonstration projects, and (iv) seeking to identify and promote the adoption of best practices.

It is the premise of the IFRAM that there are many benefits to cooperation. For instance, global cooperation on the near- to intermediate-term cost-effective resolution of the top 10 to 20 materials aging issues that impact the safety-related SSCs could greatly benefit all participants. A second example is cooperation in adopting best practices in NPPs - including operational principles, practices, and improvement measures - that are believed to have contributed to improved performance, operation, and safety of NPPs. IFRAM will act to promote the adoption of these best practices, especially those practices that pertain to life extension of NPPs. Cooperation is the primary purpose of the IFRAM.

IFRAM will promote the sharing of existing and future information as a way to improve the quality of decisions made about materials aging management. IFRAM will act as a catalyst to help individuals, groups, and organizations find ways to work together on issues of common interest. This can speed reaching solutions to issues, reduce costs, and increase the value of the results. Therefore, IFRAM will:

- Foster initiation of joint research and development projects where the participants share expertise and expenses,

- Promote use of round robins such as exchange of samples, and

- Promote publication of results and insights, including IFRAM reports. 


\subsection{Benefits}

IFRAM will be mutually beneficial for all participants. However, whereas the costs of such participation are immediate, the benefits are in the future. Often people and organizations do not understand the value that participation and cooperation create. Frequently, joint efforts do not yield immediate and obvious results; therefore, in the near term, it is important to look at the benefits given by participation and cooperation. The evaluation metrics should be efficiency, quality improvements, and new ideas. What are the effects of new ideas? What are the effects of improved quality? What are the effects of increased efficiency?

In the long run, some of the expected benefits of participation are sharing, saving, increasing, and targeting:

Sharing: ideas, knowledge, identification of high-priority problems, how to derive knowledge, trends and directions, access to historic data, lessons learned, best practices, skills, expertise, access to experts, access to shared facilities, data including materials data, problems and accidents information, information on successful proactive actions, regulations, program information - who is doing what, newest technology, standards, facilities and infrastructure.

Saving: time, effort, money, and lives...doing more with less and doing it better! Better coordination among programs means savings.

Increasing: use of successful practices, quality of outcomes, degree of consensus on issues, value of national programs, shared resources, cooperation, and innovation.

Targeting: key technical areas such as 1) critical aspects of materials and their degradation mechanisms, including potential future degradation in operating plants; 2) improving the effectiveness of in-service inspection (ISI), condition-based maintenance (CBM), and on-line monitoring and prognostics (OLMP); 3) probabilistic risk assessments to support reactor aging management; and 4) development of new and improved mitigation and repair strategies and their potential effects on ISI, CBM, and OLMP.

Many countries have national programs and international agencies have activities that address aging management: United States, Japan, Korea, France, Russia, Sweden, Taiwan, Organisation for Economic Co-operation-Nuclear Energy Agency (OECD-NEA), IAEA, European Union/European Commission (EU/EC), and others. Participation benefits could be increased by having people from various national programs work together to identify the high-priority aging management research topics. Research would include analytical, computational, and tool-building activities that would be listed in some agreed-upon categories. Cooperating on this work would provide the mechanism for minimizing unnecessary duplication of efforts. The listing would note near-, medium-, and long-term efforts and aid in finding partners for cooperation. This listing would also provide a starting point in developing plans for aging management research nationally and globally.

In some countries, aging management programs are linked with various international programs. However, in other cases, the programs are focused in a regional manner, addressing specific needs among a few countries. Therefore, each participating country of IFRAM should develop a listing of various aging management research topics that need to be conducted (which would include the activities they have on-going or planned). However, since the various international activities and national activities may 
sometimes overlap, these individual listings would then be consolidated into a master list by IFRAM, which would then be used as a mechanism to prioritize and coordinate research efforts into aging management. This would minimize unnecessary duplication of efforts and would allow for increased leveraging of resources. The listing should also be in some agreed-upon categories among participants to gain mutual benefits. Some categories that need to be taken into account are:

- evaluation of degradation mechanisms

- inspection, examination, and monitoring

- mitigation, repair, and replacement, etc.

Potential research topics in the IFRAM are not limited to physical experiments, and they could also bear the nature of analytical, computational, or tool-building effort. The listing provided by each participating country or organization should be prioritized. All listed tasks should be categorized, according to the facts of whether they are upon immediate demand and their expected times to accomplishment. For relatively urgent tasks, they should be put into the category of near-term tasks and the expected time to accomplishment should be within 3 to 5 years. Similarly, for the medium-term and the long-term tasks, the expected times to accomplishment are within 5 to 10 years and more than 10 years, respectively.

With this listing posted on the website of IFRAM, it would be convenient for each participating country to find out what types of research the others are doing regarding aging management and to locate the most appropriate partners to collaborate. In the meantime, a participating country could examine what others are doing and how they have planned for aging management research. It would help this particular country to develop its own program or to revise or modify its existing program, based upon what it has learned from others. Eventually, the listings from all participating countries, through deliberate sorting and integration, would aid IFRAM to develop feasible approaches to global aging management research.

In addition to the listing, each participating country or organization should provide points of contacts (POCs) to IFRAM. In this manner when collaboration is needed, the POCs provide a way to foster open communication.

\subsection{Desired Attributes}

If IFRAM has the proper attributes, it will be able to achieve its mission and purpose in an efficient, timely manner. It is the goal of IFRAM to seek the following desired attributes. Over time these attributes will become IFRAM's hallmarks.

Focused: Be aware of emerging concerns and intentionally concentrate on the most urgent things. IFRAM works to build consensus among participants on issues and actions. It encourages existing cooperative efforts and develops cooperation on other high-priority issues. The focus on issues of common interest speeds work, reduces costs, and increases the value of results.

Open: Open participation to all individuals, groups, and organizations with interests in reactor aging management. IFRAM has a place for individuals, groups, and organizations to participate. It expects all participants to share the responsibility, be accountable, provide resources, and receive important benefits. 
Independent: Not subject to control by others. IFRAM sets its own directions. It is not led by any one person, group, or organization. It is not regulatory-led, utility-led, university-led, etc. It is free to cut across numerous kinds of boundaries to forge cooperative efforts.

Virtual: Exists virtually in form and work methods—not located in any one place. IFRAM uses virtual co-location of project staff, resources, and results. It makes extensive use of emails, conference calls, on-line meetings, websites, web conferencing, and other internet tools to facilitate work. It works with existing entities and planned activities to promote global cooperation on reactor aging management. This includes taking advantage of hosting meetings in conjunction with meeting planned by other groups. The activities are adjunct to these efforts or even made a planned part of them.

Technical: Known to have and use special practical knowledge to address issues. IFRAM aims to build its reputation as "the source" of knowledge and expertise and "a thought leader" in the field of plant life management for nuclear power plants. It provides leadership in consolidating available information, coordinating activities, and bringing together different national and regional views on topics. It harmonizes agreed-upon best practices and forms technical focus groups to address high-priority issues. IFRAM is a leader in qualifying data.

Resourceful: Capable of devising ways and means to be successful. IFRAM invites participants to provide resources including funding for its activities. It pursues the role of building cooperation and but it does not enter role of funding projects and activities. It is not a funding agency. It promotes projects that involve large sums of money but it does not control a budget for the work. IFRAM uses the existing global talent pool and encourages knowledge transfer to emerging technical experts. This approach helps IFRAM to achieve its objectives. Since participants organize and lead activities, IFRAM does not maintain a staff. It capitalizes on participants with interest, initiative, ideas, and resources to make things happen. Leadership roles are assigned to those who are willing to support the mission.

Flexible: Capable of quickly adapting to new, different, or changing requirements. IFRAM is nimble in planning, decision-making, and taking actions. Its flat organization structure makes it possible to be quick in cooperating with others.

Sharing: Appropriately distributes the benefits of cooperation to participants. IFRAM promotes the sharing of ideas and innovation, knowledge and data-trend and directions plus historic data, high-priority issues, and lessons learned and best practices including information on successful proactive actions. It communicates 1) information on skills and expertise - who is doing what and where, 2) information on facilities - newest technologies and capabilities, and 3) changes in standards and codes.

Beneficial: Provides advantages to all who participate. The cooperation IFRAM facilitates provides benefits not readily achievable by working independently. It gives participants opportunities to save time, effort, and money. Advancing plant life management methods provides gains in regulatory efficiency, which in turn delivers large economic savings.

\subsection{Engagement}

IFRAM will focus on building cooperation among existing and developing programs rather than funding and/or initiating new directly-funded research projects. It will identify high-priority issues and facilitate joint projects among parties with mutual interests on specific issues. It is expected that the 
parties involved in the forum will provide resources for the work. A flat, flexible organizational structure will be used to facilitate issue-oriented cooperation. The International Forum will be a functional entity designed to achieve its purpose and objectives. While it may become a legal entity at some point, this is not required for its implementation. An important step for IFRAM is to communicate its value proposition to others. IFRAM could be included in international agreements or engage as a part of officially sanctioned activities of IAEA or OECD-NEA, Structural Mechanics in Reactor Technology (SMIRT) and Pressure Vessels and Piping (PVP), and others. 



\subsection{Inaugural Meeting}

\subsection{Venue}

The inaugural meeting of the International Forum for Reactor Aging Management (IFRAM) was held on August 4-5, 2011, at the Cheyenne Mountain Resort in Colorado Springs, Colorado. Mr. Gene Carpenter was the meeting host on behalf of the U.S. Nuclear Regulatory Commission. Dr. Leonard Bond and Dr. David Brenchley were IFRAM Secretariat staff responsible for leading and facilitating the meeting. Becky Ford made all of the local arrangements while Mary Ramos prepared the meeting materials.

\subsection{Meeting}

Meeting objectives determined the design of the meeting agenda and the work of the newly formed Leadership Council. The objectives were to:

- Affirm the purpose, nature, benefits, and working aspects of IFRAM.

- Hear regional reports on present and future IFRAM activities in Asia, Europe, and the United States.

- Initiate some technical focus groups to address important reactor aging management issues.

- Stimulate the development of collaborative efforts to address R\&D on reactor aging management issues.

- Affirm organization and leadership for the next year.

- Review calendar of IFRAM-related events and activities.

The following agenda provided activities and time to accomplish all of these objectives.

\section{Thursday, August 4}

\section{Mountain View Restaurant}

\section{6:30-8:00 am Buffet Breakfast (no charge)}

\section{White River Ballroom}

Dr. Leonard Bond, Secretary to IFRAM Leadership Council

Dr. David Brenchley, Facilitation Leader

\section{7:45 am Kick Off}

Welcome

Introductions 
8:00-10:30 am IFRAM -- Promoting international cooperation in reactor aging management

Asia Professor T. Shoji, Tohoku University, Asian Activities of Nuclear Power Plant Aging Management

Professor Il Soon Hwang, Seoul University, Proactive Materials Degradation Management in Korea

Europe Dr. Oliver Martin, European Commission: Institute for Energy, Nuclear Power Generation in Europe and European Level R\&D on Reactor Ageing Management

Dr. Valery Prunier, EdF, representing NULIFE ExeGroup, European PLIM activities under SNETP and NULIFE

USA Mr. Garry Young, Entergy Nuclear, License Renewal and LTO in the U.S.

Mr. Gene Carpenter, U.S. Nuclear Regulatory Commission, Promoting International Cooperation In Reactor Aging Management - USNRC Perspective

\section{0:30-11:00 am BREAK}

\section{1:00 am-12:30 pm Establishing Focus Groups}

\section{On-line Monitoring}

Dr. Jeremy Busby, Oak Ridge National Laboratory, Materials Aging and Degradation: Needs and Opportunities for Better NDE

Dr. Leonard Bond, PNNL, On-Line Monitoring Activities \& Potential

\section{Plant Life Extension Guidelines}

Professor Tetsuo Shoji, Tohoku University, Current Status of Plant Life Management in Japan

Dr. Jan Van Der Lee, Director, The Materials Ageing Institute (MAI), Plant Life Extension Guidelines

Dr. Amy Hull, N U.S. Nuclear Regulatory Commission, Generic Aging Lessons Learned (GALL)

\section{2:30-1:30 pm Buffet Lunch (no charge) - Mountain View Restaurant}

\section{$1: 30$ pm Groups Convene}

On-Line Monitoring Focus Group

Plant Life Extension Guidelines Focus Group

\section{4:00-5:00 pm Focus Group Reports \& Discussion}

Proposal to Establish On-line Monitoring Focus Group.

Revised Title: Technologies for Monitoring Aging and Materials Degradation 
Proposal to Establish Plant Life Guidelines Focus Group.

Revised Title: Proposal to Establish Focus Group to Determine Technical Issues related to Plant Life Management

5:00 pm Signing Event for Kick Off of IFRAM

IFRAM Kick-Off Meeting Certificate

6:30 pm No-Host Dinner - The Pineview Grille at the Country Club

\section{Friday, August 5}

\section{Mountain View Restaurant}

6:30-8:00 am Buffet Breakfast (no charge)

\section{White River Ballroom}

Dr. Leonard Bond, Secretary to Leadership Council

Dr. David Brenchley, Facilitation Leader

\section{7:45 am Getting Started}

Welcome

Announcements

8:00-8:30 am Plenary Session

Ki Sig Kang, Nuclear Power Division, IAEA,The Need of International Cooperation and Previous Experiences

\section{8:30-10 am Panel Discussion}

\section{Topic: Collaborative Research in Reactor Aging Management_Post Fukushima}

Mr. Gene Carpenter, U.S. Nuclear Regulatory Commission, NRC Near-Term Task Force Review of Insights from the Fukushima Dai-Ichi Accident

Professor Il Soon Hwang, Seoul University, Summary of PRIMA-NET Survey on IFRAM Focus-Topics

Dr. Jan Van Der Lee, Director, The Materials Ageing Institute (MAI), Material Research to Support Safe Long-Term Operation Status and Perspectives of the MAI

\section{0:00-10:30 am Break--Refreshments in Open Area}




\title{
10:30 am-12:30 pm Breakout Groups on Collaborative Research Topics
}

Each group discusses potential collaborative research topics. Which topics are the most important and how might international cooperation be used to speed the R\&D work?

\section{2:30-1:30 pm Buffet Lunch (no charge) - Mountain View Restaurant}

\section{1:30-3:00 pm Breakout Group Reports and Discussion}

Each group reports on their deliberations followed by an open discussion period.

Group 1: Recommended Collaborative Research Topics

Group 2: Recommended Collaborative Research Topics

3:00-5:00 pm Ideas for Future IFRAM Activities

Brainstorming Activity: "One thing I want IFRAM to do is....."

Discussion of planned IFRAM activities-short-term and long-term.

\author{
5:00 pm Adjourn Meeting \\ 6:30 pm Nost IFRAM Leadership Council Dinner Meeting
}

\subsection{Participants}

Participants from Asia, Europe, and the United States gathered for this inaugural event. It was evident that the energy and commitment generated in the engagement workshops had carried over to this "Kick-Off" meeting. The goal of 30 participants was exceeded. Table 2.1 lists the people who participated. 
Table 2.1. Participants in IFRAM "Kick-Off" Meeting

\begin{tabular}{|c|c|}
\hline Name & Organization \\
\hline Behravesh, Mohamad M. & $\begin{array}{l}\text { Electric Power Research Institute (EPRI) and the Materials Aging Institute } \\
\text { (MAI) }\end{array}$ \\
\hline Bezdikian, Georges & Georges Bezdikian Consulting Co. \\
\hline Bond, Leonard & Pacific Northwest National Laboratory \\
\hline Brenchley, David & Pacific Northwest National Laboratory \\
\hline Brumovsky, Milan & Nuclear Research Institute Rez plc \\
\hline Busby, Jeremy & Oak Ridge National Laboratory - UT/Battelle \\
\hline Carpenter, C. E. (Gene) & US Nuclear Regulatory Commission \\
\hline Changhgui, Jang & KAIST \\
\hline Dobmann, Gerd & Fraunhofer-Institute IZFP \\
\hline Han, En-Hou & Institute of Metal Research, Chinese Academy of Sciences \\
\hline Herter, Karl-Heinz & MPA University Stuttgart \\
\hline Hill, Carolyn & S.M. Stoller Corporation \\
\hline Hines, J. Wesley & The University of Tennessee \\
\hline Huang, Jiunn-Yuan & Institute of Nuclear Energy Research \\
\hline Hull, Amy B. & US Nuclear Regulatory Commission \\
\hline Hwang, II Soon & Seoul National University \\
\hline Hwang, Seong Sik & Korea Atomic Energy Research Institute \\
\hline Jeong, Yong Hwan & Korea Atomic Energy Research Institute \\
\hline Kang, Ki Sig & International Atomic Energy Agency (IAEA) \\
\hline Kang, Sung-sik & Korea Institute of Nuclear Safety (KINS) \\
\hline Karlsen, Wade & VTT Technical Research Centre of Finland \\
\hline Lee, Bong Sang & Korea Atomic Energy Research Institute \\
\hline Lee, Jan van der & EDF, Materials Ageing Institute \\
\hline Martin, Oliver & $\begin{array}{l}\text { European Commission, Joint Research Centre (JRC) - Institute for Energy } \\
\text { (IE) }\end{array}$ \\
\hline Miura, Yasufumi & Central Research Institute of Electric Power Industry \\
\hline Prunier, Valery & EDF, Representing NULIFE \\
\hline Rusaw, Richard & Electric Power Research Institute \\
\hline Ruscak, Martin & Research Centre Rez plc \\
\hline Sakakibara, Yohei & IHI Corporation \\
\hline Sakamoto, Kazunobu & Japan Nuclear Energy Safety Organization \\
\hline Shoji, Tetsuo & Tohoku University \\
\hline Stjarnsater, Johan & Studsvik Nuclear \\
\hline Tawfik, Magdy S. & Idaho National Laboratory \\
\hline Tilley, Richard & Electric Power Research Institute \\
\hline Usrey, Michael & Sporian Microsystems, Inc. \\
\hline Watanabe, Yutaka & Tohoku University \\
\hline Yeh, Tsung-Kuang & National Tsing Hua University \\
\hline Yonezawa, Toshio & FRRI - Tohoku University \\
\hline Yoon, Jae Young & Seoul National University \\
\hline Young, Garry G. & Entergy Nuclear \\
\hline
\end{tabular}




\subsection{Outcomes}

The meeting was gaged a major success. Everyone participated and stayed for the two days of activities. The main outcomes of the meeting were:

- Fifteen presentations on reactor aging management activities.

- A proposal to establish a Focus Group on “Technical Issues Related to Plant Life Management."

- A proposal to establish a Focus Group for "Technologies for Monitoring Aging and Materials Degradation."

- Signing ceremony of IFRAM Kick-Off Meeting Participants.

- List of Recommended Collaborative Research Topics. Recommended actions were proposed for the highest priority topics.

- List of ideas that participants want IFRAM to do.

- Election of Professor Tetsuo Shoji as Chairperson of the Leadership Council.

- List of future activities for IFRAM.

The meeting presentations and Focus Group presentations were sent to all participants on CDs. The outcomes were also posted on the IFRAM website: http://ifram.pnnl.gov. 


\subsection{Presentations}

This section provides brief abstracts of the presentations from the inaugural meeting. The full presentations are on the $\mathrm{CD}$ included with this report.

\section{SESSION TOPIC: IFRAM - Promoting international cooperation in reactor aging management.}

This session provides reports from Asia, Europe, and the United States.

- Professor T. Shoji, Tohoku University, Asian Activities of Nuclear Power Plant Aging Management

This presentation includes contributions by Prof. En-Hou Han, Prof. T. K. Yeh, Dr. J. Y. Huang, Dr. Clinton Fong, and Prof. Yang Wu. It gives information on NPPs and research organizations for the following countries: China, Korea (by Prof. Il Soon Hwang in the next presentation), Japan, Taiwan, and India.

- Professor Il Soon Hwang, Seoul University, Proactive Materials Degradation Management in Korea This presentation reports on PMMD and PRIMA-NET activities in Korea. Sections include:

Phase One (2008-2011): Achievements

Phase Two (2012-2014): Plan

IFRAM and Future of Korean Nuclear Power Program

- Dr. Oliver Martin, European Commission: Institute for Energy, Nuclear Power Generation in Europe and European Level R\&D on Reactor Ageing Management

This presentation reports on nuclear power generation in EU Member Countries, nuclear power generation in EU neighboring countries and European level R\&D on reactor aging management. For each country, information is reported on numbers and types of reactors, ages and the status of operations, and R\&D efforts on reactor aging management.

- Dr. Valery Prunier, EdF, representing NULIFE ExeGroup, European PLIM activities under SNETP and NULIFE

This presentation reports on: 1) The European context: from the Sustainable Energy Technology (SET) Plan to Sustainable Nuclear Energy Platform (SNETP); 2) NULIFE: the European Network of Excellence on PLIM; and 3) future integration of Gen II\&III activities. The history, approach, and work processes of NULIFE are described; its priorities are:

1. European harmonised plant design and safety justification methodology

2. Integrity assessment

3. Aging mechanisms of structures, systems, and components

4. Aging monitoring

5. Prevention and mitigation of aging

6. Pre-normative research, codes and standards

7. Safety issues in instrumentation \& control and electrical systems

8. Human factors and man-machine interaction 
Conclusions are:

- NULIFE has a proven structure and operating model to manage collaborative R\&D in Europe.

- NULIFE is a simple process for project identification, evaluation, planning, contracting, and running.

- NULIFE is evolving into an Association in October 2011, open to all nuclear stakeholders.

- Integration of NULIFE, SARNET, and SNETP TWG Gen II\&III will simplify, accelerate, and also improve implementation.

- Mr. Garry Young, Entergy Nuclear, License Renewal and LTO in the United States

This presentation describes Entergy Nuclear and depicts the potential U.S. electrical energy problem if current operating nuclear units are not granted license renewals for LTO. Integrated plant assessment and the NRC license renewal review process are given. The conclusion states:

The U.S. must maintain Safety, Performance, Cost, Environmental, and Public Opinion of existing NPPs (LTO). International Information Exchange is Critical to Success!

- Mr. Gene Carpenter, U.S. Nuclear Regulatory Commission, Promoting International Cooperation In Reactor Aging Management - USNRC Perspective

This presentation stresses that participants are present to develop an organization to facilitate the appropriate exchange of information among global organizations that are addressing NPP Aging Management Issues. This will be accomplished by (i) cooperating to achieve common objectives; (ii) sharing information/data; (iii) entering into joint research/demonstration projects; and (iv) seeking to identify and promote the adoption of best practices.

Area for possible cooperation include:

- dissimilar welds

- reactor vessel embrittlement

- fatigue

- stress corrosion cracking

- electric cables

- concrete

- fatigue

- irradiation effects

- regulatory issues

- codes and standards

- spent nuclear fuel storage

- nondestructive examination

- information sharing 
Conclusions are:

- Research is necessary to establish basis for long-term operation of existing nuclear plants beyond 60 years, and this research will:

- Answer safety questions on aging, reliability, and long-term operability of systems, structures and components

- Industry has lead role to drive the process and identify issue resolutions

- Ultimately, life extension is utility business decision

- NRC ensures that safety-significant issues are identified and resolved in a timely manner

○ It is not NRC's responsibility to resolve any potential aging issues that may impact continued safe operation of existing fleet

- NRC seeking to cooperate/collaborate with DOE, domestic industry, and international partners in an integrated, holistic program to ensure long-term safety.

\section{SESSION TOPIC: Establishing Focus Groups}

The presentations in this session cover two areas that IFRAM wants to initiate Focus Groups.

- Dr. Jeremy Busby, Oak Ridge National Laboratory, Materials Aging and Degradation: Needs and Opportunities for Better NDE

It is noted in this presentation that:

1. Materials research is already a key need for the existing nuclear reactor fleet

2. Materials degradation can lead to increased maintenance, increased downtime, and increased risk.

3. Materials issues must be resolved for:

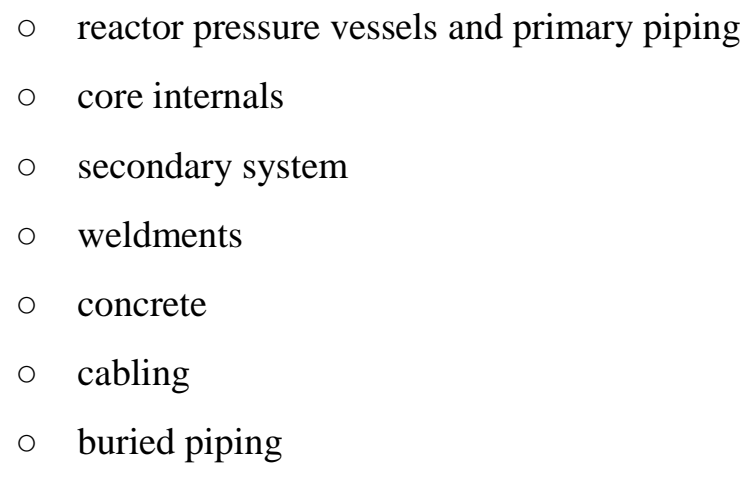

4. Increased lifetime leads to increased exposures

○ time at temperature

- stress

- coolant

$\circ$ neutrons 
5. Extending reactor life to 40,60 years or beyond will likely increase susceptibility and severity of known forms of degradation

6. New mechanisms of materials degradation are possible

7. There are few ways to ensure material integrity throughout life: replace, over-engineer, understand all forms of degradation, or monitor.

- Dr. Leonard Bond, PNNL, On-Line Monitoring Activities \& Potential

This presentation provides the background for on-line monitoring activities. It covers active components for on-line monitoring and passive components in NDE and on-line monitoring. The main conclusions are:

1. The growing global interest in the longer term operation (LTO) of the existing fleet of nuclear power plants is being supported by developments in plant life strategies.

2. New designs - both SMR and novel concepts all require on-line monitoring

3. Proactive approaches implemented using on-line monitoring have the ability to both constrain operations and maintenance costs and provide plant operators with greater plant condition awareness.

4. Increased condition awareness will support better economic assessments of life costs and help to ensure continued safe operation as plants operate longer.

- Professor Tetsuo Shoji, Tohoku University, Current Status of Plant Life Management in Japan

This presentation outlines:

1. Japanese nuclear power plants and the status of the aging management,

2. 2010-2011 rolling of the strategy map for aging management

- Improvement of technical information infrastructure

- Promotion of safety research activity

- Promotion of international cooperation

$\circ$ Improvement of codes and standards

3. NISA's New Research Program on Aging Management - "JAMP”

Summary points are:

- Japanese government (NISA) permitted operation's continuation to total 20 NPPs as the result of 1st AM Technical Evaluation (30 years), and 2 NPPs of 2nd AMTE (40 years) as of the end of 2010. 
- New comprehensive regulatory inspection system established in 2009 has made the ageing management continuous and seamless by the combination of the periodic regulatory inspection, PSR, and AMTE before 30 years operation and in every ten years.

- The STRATEGY MAP to make up Technical Information Infrastructure (Code \& Standard, technical data from safety research, etc.) in cooperation with industry, academia, and government is effective navigator for AM, LTO, and PLiM.

- The noteworthy issues are made as a consensus among three stake holders from the viewpoint of the technical information infrastructure, safety research and development, international cooperation and codes \& standards.

- As the result of rolling of the STRATEGY MAP, the total budget of stakeholders increase for AM, LTO, and PLiM.

- Safety research used aged and/or irradiated actual plant material, clarification of degradation mechanism, and prediction of the proactive and/or cluster phenomenon will be important in the next ten years for proactive aging management.

- Dr. Jan Van Der Lee, Director, The Materials Ageing Institute (MAI), Plant Life Extension Guidelines

Comments note:

- Materials aging management is not only an issue for long-term operation, it impacts overall performance; e.g., safety, availability, environmental concern, dose...

- Degradation mechanisms must be fully understood for safety, sustainable solutions and optimized life management

Important priorities are:

- What defines the end of life of an NPP? Component obsolescence, costs

- Are "consumables" a priority?

- Replaceable vs. unreplaceable components...

- How can we be proactive in an efficient manner (or how to foresee the unforeseeable ...)?

- Dr. Amy Hull, N U.S. Nuclear Regulatory Commission, Generic Aging Lessons Learned (GALL)

Based on the Atomic Energy Act, the NRC issues licenses for commercial power reactors to operate for up to 40 years and allows these licenses to be renewed for up to another 20 years. To date, the NRC has approved license renewal for well over 50\% of the 104 reactors in the United States originally licensed to operate for 40 years. There are now about 10 reactors in the first period of extended operation, and there is increasing interest in subsequent license renewal and NPP LTO beyond 60 years. One foundation of the license renewal process has been license renewal guidance documents such as the GALL Report (NUREG-1801, Rev. 2; NRC 2010b), the License Renewal Standard Review Plan (NUREG-1800, NRC 2010a), which completed its second revision in January 2011. The GALL Report evaluates several thousand NPP components, identifies the significant aging effects, and provides an acceptable aging management program for the component.

- The GALL Report is now a single volume. 
- Guidance related to the ASME Code now identifies which editions are acceptable; and clarifies how ASME code cases and reliefs apply in the period of extended operation.

- All Aging Management Programs (AMPs) were updated to reflect recent operating experience, license renewal precedents, changes in NRC regulations, content of license renewal Interim Staff Guidance, and changes in industry codes and standards, and were aligned with the revised AMP 10-element template.

- A number of "further evaluation required" items in the Safety Review Plan for License Renewal (SRP-LR) were eliminated based on experience or that the associated AMP was enhanced.

- $\quad$ The SRP-LR was aligned with the changes made in the GALL Report aging management review (AMR) line items.

- New AMPs and associated AMR line items were added.

- The companion technical basis and public comment disposition document (NUREG-1950) (NUREG-1950, NRC 2011) was issued on April 30, 2011.

\section{SESSION TOPIC: Focus Group Reports and Discussion}

- Dr. Leonard J. Bond (group leader), Proposal to Establish On-line Monitoring Focus Group. Revised Title: Technologies for Monitoring Aging and Materials Degradation

This group recommended the following:

- Focus on early degradation (i.e., precursors prior to crack initiation) in metallic materials (potentially including radiation damage of internals)

- FAC

$\circ$ Vibration fatigue

- Precursor states to crack initiation (SCC)

- Thermal, mechanical fatigue

- Potentially expand scope-ASME Section XI criteria for FAC, EAC, degradation mechanisms

- Methods to detect and measure the different mechanisms - basis for measurements needed to obtain actionable data.

- Mr. Gene Carpenter (group leader), Proposal to Establish Plant Life Guidelines Focus Group. Revised Title: Proposal to Establish Focus Group to Determine Technical Issues Related to Plant Life Management

This group recommended the following:

- Develop a LIVING quantified listing of test facilities and their capabilities, regional subject matter experts, and proposed/on-going research by organization

- Develop and implement regional framework to get regulators, industry (utilities and vendors), academia, and TSOs to cooperate on the development of data needed for aging management activities 
Technical research areas:

- Develop model of impact of differing operating conditions globally

$\circ$ Including mitigation activities

- Develop model of civil structures (concrete) in normal and aggressive environments

- Develop better understanding of cable aging (share existing research and develop cooperative path forward)

- Develop better understanding of (IA)SCC (share existing research and develop cooperative path forward)

- Develop better understanding of fatigue (share existing research and develop cooperative path forward)

- Develop better understanding of radiation embrittlement (share existing research and develop cooperative path forward)

\section{SESSION TOPIC: Signing Event for IFRAM Certificate}

- IFRAM Certificate Signed by All Participants

All meeting participants signed four IFRAM certificates. These were distributed to representatives from Asia, Europe, United States, and the IFRAM Secretariat.

\section{SESSION TOPIC: Plenary Session}

- Ki Sig Kang, Nuclear Power Division, IAEA, The Need of International Cooperation and Previous Experiences

This presentation stresses the need for information sharing and dissemination. This subject was one of five suggestions from Fukushima lessons learned and experience. Three examples of outputs through international cooperation are noted:

- $\quad \mathrm{D} / \mathrm{B}$ of reactor vessel materials

- Unified procedure for lifetime assessment of components and piping of WWER NPPs

- International Generic Ageing Lessons Learned (IGALL)

The $3^{\text {rd }}$ International Conference on Nuclear Power Plant Life Management to be held in Salt Lake City in May 14-18, 2012, is presented as an opportunity for building international information sharing.

\section{SESSION TOPIC: Panel Discussion on Collaborative Research in Reactor Aging Management- Post Fukushima}

- Mr. Gene Carpenter, U.S. Nuclear Regulatory Commission, NRC Near-Term Task Force Review of Insights from the Fukushima Dai-Ichi Accident

Comments summarize the work of the NRC Near-Term Task Force Review of Insights from the Fukushima Dai-Ichi Accident. 
- Professor Il Soon Hwang, Seoul University, Summary of PRIMA-NET Survey on IFRAM Focus Topics

Presentation describes the development of list of topics for IFRAM Focus Groups and the subsequent efforts of the PRIMA-NET to review and evaluate and validate the list.

Summary of events and results:

- Focus Group Topics - drafted.

- Focus Group Sub-Topics - drafted.

- Korean PRIMA-NET Revised and Proposed

- Safety improvement as a key criteria

- Fukushima action not related with aging is set aside.

- PRIMA-NET survey made.

○ Q1: Importance in Safety and Economy

$\circ \quad$ Q2: Ongoing Activity Levels (High $\geq \$ 100 \mathrm{~K} / \mathrm{yr}$ )

○ Q3: Future Plan \& Commitment

- Correlation of Survey Results

○ Poor Correlation between Q1 \& Q2

○ Good Correlation between Q1 \& Q3

- Poor Correlation between Q2 \& Q3

- Korean survey confirms Potential IFRAM Benefit.

- Dr. Jan Van Der Lee, Director, The Materials Ageing Institute (MAI), Material Research to Support Safe Long-Term Operation Status and Perspectives of the MAI

Comments summarize the materials research at the Materials Aging Institute (MAI) to support safe long-term operations of NPPs in France. The work of MAI supports 58 operating reactors; its major objectives are to:

- Contribute to safe operation of NPPs through anticipation and management of materials and components.

- Create a place to centralize R\&D and to share feedback from NPPs, data, methods, models, and expertise.

- Contribute to the training courses and seminars in the field of material aging.

- Improve knowledge on aging mechanisms with help of powerful experimental means.

Conclusions regarding Post Fukushima are:

1. Impact of Fukushima is minor for material aging, unknown for new build

2. MAI developments 
- Three years after its creation, ambitions are confirmed (e.g., MAI-LEF).

- Strong interactive partnerships: a huge potential for efficient $R \& D$, breakthroughs, and costsavings.

- Major scientific achievements and successful training sessions.

- MAI is increasingly used for communication purposes.

3. MAI and IFRAM interaction

- IFRAM helps MAI to define and establish projects, by providing expertise and networking.

- MAI is a platform to realize the projects.

\section{SESSION TOPIC: Group Reports and Discussion}

The recommendations of the working groups provide IFRAM with direction for promoting cooperation on research projects.

- Dr. Leonard J. Bond (group leader), Recommended Collaborative Research Topics

This focus group recommended:

- Concrete performance and surveillance techniques

- OLM, condition assessment, and sensor placement

- Irradiated materials welding

- Cables (coatings and polymeric materials)

- Gene Carpenter (group leader), Recommended Collaborative Research Topics

The focus group recommended:

- Develop a LIVING quantified listing of test facilities and their capabilities, regional subject matter experts, and proposed/on-going research by organization

- Develop and implement regional framework to get regulators, industry (utilities and vendors), academia, and TSOs to cooperate on the development of data needed for aging management activities

Technical research areas:

- Develop model of impact of differing operating conditions globally

- Including mitigation activities

- Develop model of civil structures (concrete) in normal and aggressive environments

- Develop better understanding of cable aging (share existing research and develop cooperative path forward)

- Develop better understanding of (IA)SCC (share existing research and develop cooperative path forward) 
- Develop better understanding of fatigue (share existing research and develop cooperative path forward)

- Develop better understanding of radiation embrittlement (share existing research and develop cooperative path forward)

\section{SESSION TOPIC: Ideas for Future IFRAM Activities}

This brainstorming activity provided a wealth of ideas for future IFRAM activities.

- David Brenchley (leader), "One thing I want IFRAM to do is....."

Participants contributed many ideas for future IFRAM activities. These ideas will be used by the Leadership Council and others to form IFRAM's agenda for action. The ideas were submitted for the following areas:

- Gathering data and knowledge

- Information sharing

- Research and development

- Communication

- Meeting format

- Resources

- Education and training

- Planning

- Reviews

- Regulation

- Guidelines

- Testing 


\subsection{References}

Andresen PL, FP Ford, K Gott, RL Jones, PM Scott, T Shoji, RW Staehle and RL Tapping. 2007. Expert Panel Report on Proactive Materials Degradation Assessment. NUREG/CR-6923, BNL-NUREG77111-2006, U.S. Nuclear Regulatory Commission, Washington, D.C.

Bond LJ, SR Doctor and TT Taylor. 2008. Proactive Management of Materials Degradation - A Review of Principles and Programs. PNNL-17779, Pacific Northwest National Laboratory, Richland, Washington.

NRC. 2005a. Generic Aging Lessons Learned (GALL) Report-Summary. NUREG-1801, Vol. 1, Rev. 1, Office of Nuclear Reactor Regulations, U.S. Nuclear Regulatory Commission, Washington, D.C.

NRC. 2005b. Generic Aging Lessons Learned (GALL) Report - Tabulation of Results. NUREG-1801, Vol. 2, Rev. 1, Office of Nuclear Reactor Regulations, U.S. Nuclear Regulatory Commission, Washington, D.C.

NRC. 2010a. Final Report - Standard Review Plan for Review of License Renewal Applications for Nuclear Power Plants. NUREG-1800, Rev. 2, U.S. Nuclear Regulatory Commission, Washington, D.C.

NRC. 2010b. Generic Aging Lessons Learned (GALL) Report - Final Report. NUREG-1801, Rev. 2, Office of Nuclear Reactor Regulations, U.S. Nuclear Regulatory Commission, Washington, D.C.

NRC. 2011. Disposition of Public Comments and Technical Bases for Changes in the License Renewal Guidance Documents NUREG-1801 and NUREG-1800. NUREG-1950, U.S. Nuclear Regulatory Commission, Washington, D.C. 



\begin{abstract}
Appendix A
Instructions for Focus Group "Plant Life Extension Guidelines"
\end{abstract}





\section{Appendix A}

\section{Instructions for Focus Group "Plant Life Extension Guidelines"}

IFRAM will establish a Focus Group for "Plant Life Extension Guidelines.” Your help is needed.

Your Purpose: Create a draft proposal (in Power Point format) for establishing IFRAM's "Plant Life Extension Guidelines Focus Group." Based on your work, a written proposal will be submitted to the Leadership Council for review and action.

Requirements: Your Power Point proposal should contain the following sections. Add more sections if you think this would strengthen the proposal.

1. Specific Issues. What issues need to be addressed which ones are the more important ones? Provide a 2-4 sentence description of the most important issues; i.e., what is it and why is it important?

2. Potential Participants. Focus groups will have about 10-30 participants. Who are some people with the necessary credentials and interest you think might like to participate?

3. Communications. What are the ways this focus group can best work together? Can you recommend specific opportunities for group meetings? Could these be in conjunction with other technical meetings? If so, which ones? What electronic communications are suitable for the work this group has to do?

4. Outcomes. What are the accomplishments and deliverables you think this focus group could achieve?

5. Duration. How long do you see this focus group needing to be active?

6. Other Comments. What other comments or recommendations do you have?

7. Contributors. List people in this group.

\section{Getting Started}

Step 1. Greet and meet each other. Make a list of who is in the Focus Group.

Step 2. Use 5 to 10 minutes of silent reading time. Read Charter Section 2.3 and Operations Guidelines Section 5.0.

Step 3. You will need someone to work the computer to develop the Power Point slides as the group does its work. Please use the "Thumb Drive" that is provided to this group; it has template slides on it.

Step 4. Discuss each section of your proposal. Use flip chart and yellow stickies to record ideas and comments.

Step 5. Polish your Power Point presentation and decide who is going present it. 



\section{Appendix B}

\section{Instructions for Focus Group}

"On-line Monitoring" 



\section{Appendix B}

\section{Instructions for Focus Group "On-line Monitoring",}

IFRAM will establish a Focus Group for “On-line Monitoring.” Your help is needed.

Your Purpose: Create a draft proposal (in Power Point format) for establishing IFRAM's "On-Line Monitoring Focus Group." Based on your work, a written proposal will be submitted to the Leadership Council for review and action.

Requirements: Your Power Point proposal should contain the following sections. Add more sections if you think this would strengthen the proposal.

1. Specific Issues. What issues need to be addressed which ones are the more important ones? Provide a 2-4 sentence description of the most important issues; i.e., what is it and why is it important?

2. Potential Participants. Focus groups will have about 10-30 participants. Who are some people with the necessary credentials and interest you think might like to participate?

3. Communications. What are the ways this focus group can best work together? Can you recommend specific opportunities for group meetings? Could these be in conjunction with other technical meetings? If so, which ones? What electronic communications are suitable for the work this group has to do?

4. Outcomes. What are the accomplishments and deliverables you think this focus group could achieve?

5. Duration. How long do you see this focus group needing to be active?

6. Other Comments. What other comments or recommendations do you have?

7. Contributors. List people in this group.

\section{Getting Started}

Step 1. Greet and meet each other. Make a list of who is in the Focus Group.

Step 2. Use 5 to 10 minutes of silent reading time. Read Charter Section 2.3 and Operations Guidelines Section 5.0.

Step 3. You will need someone to work the computer to develop the Power Point slides as the group does its work. Please use the "Thumb Drive" that is provided to this group; it has a template slides on it.

Step 4. Discuss each section of your proposal. Use flip chart and yellow stickies to record ideas and comments.

Step 5. Polish your Power Point presentation and decide who is going present it. 



\section{Appendix C}

\section{Instructions for Breakout Groups \\ "Collaborative Research Topics in Reactor Aging Management-Post Fukushima"}





\section{Appendix C}

\section{Instructions for Breakout Groups "Collaborative Research Topics in Reactor Aging Management-Post Fukushima"}

IFRAM will promote collaborative research for Reactor Aging Management. Which research topics are best achieved through international collaborative efforts?

Your Purpose: Develop a list of potential collaborative research topics and prioritize these topics according to their relative importance in reactor aging management. For the most important topics briefly describe by answering one or more of the following questions: What is required? What kind of work is to be done? What particular aim is the cooperative enterprise going to achieve?

Requirements: Create a report (in Power Point format) summarizing your findings. Based on your advice and that of others, IFRAM will promote international cooperation to address these research topics. In your Power Point report list the top four (4) research topics that lend themselves well to an international cooperative effort. At the end of your Power Point presentation list the contributors (members of the breakout group). For each topic do the following:

1. Define Topic: What is the topic that needs to be addressed? What is it and why is it important? Provide a 2-4 sentence description to clarify it.

2. Describe Work Needed: What kind of work needs to be done? What would be the aim of a cooperative enterprise?

3. Identify Potential Participants. Who are possible participants (stakeholders) for this cooperative work?

\section{Getting Started}

Step 1. Greet and meet each other. Make a list of who is in the Breakout Group.

Step 2. Refer to Charter Section 2.3 and Operations Guidelines Section 5.0.

Step 3. You will need someone to work the computer to develop the Power Point slides as the group does its work. Please use the "Thumb Drive" that is provided to this group; it has a template slides on it.

Step 4. Identify potential research topics. Review EPRI list and discuss which topics are of interest for possible international collaborative research effort. Also note the list developed by Professor IL Soon Hwang. Discuss topic but DON'T spend too much time on this activity.

Step 5. Identify most important candidates. Use a simple voting process. SUGGESTED METHOD: Write list of topics on flip chart and number each one. Each person has three votes. The votes may be distributed or all placed on one topic. Place marks (tallies) next to the item. Total votes are then tallied. The group then selects its top topics. 
Step 6. Answer the three (3) questions for each of the selected research topics. Put answers on Power Point slides.

Step 7. Polish your Power Point presentation and decide who is going present it. 


\title{
Appendix D
}

\author{
Instructions for Brainstorming: \\ Ideas for Future IFRAM Activities
}





\section{Appendix D}

\section{Instructions for Brainstorming: Ideas for Future IFRAM Activities}

1. Silently focus on this open-ended statement: "One thing I want IFRAM to do is....." This statement is written on a flip chart in the front of the room.

2. Use the "yellow stickies." Write one or two responses that come to your mind. Write only one response on each "yellow sticky."

3. Pair up with another person. Someone sitting next to you, behind you, in front of you etc. Form teams of two. Move across the room if necessary to find a team mate.

4. Each person is to share their idea with the other person. One person will share first and the second person will be the listener. When done they reverse roles.

5. Each team comes before the total group and the members share their ideas. Then the "yellow stickies" are posted on the flip chart.

6. When all teams have shared all of the ideas are gathered up, organized according to content and then typed into one document so that all participants have the record of what was shared.

7. The Leadership Council will use these ideas in making plans for the future. 

PNNL-20719

\section{Distribution}

No. of

Copies

Busby, Jeremy

Oak Ridge National Laboratory -

UT/Battelle

PO Box 2008, Mail Stop 6138

Oak Ridge, TN 37831

Carpenter, C. E. (Gene)

US Nuclear Regulatory Commission

11555 Rockville Pike, Mail Stop CS-5-A-26

Rockville, MD 20852

Gaertner, John

Electric Power Research Institute

1300 West WT Harris Blvd.

P.O. Box 217097

Charlotte, NC 28262

Hill, Carolyn

S.M. Stoller Corporation

105 Technology Drive, Suite 190

Broomfield, CO 80021

Hines, J. Wesley

The University of Tennessee

$711 \mathrm{E}$ Anoy Holt Tower

Knoxville, TN 37996-0174

Hull, Amy B.

US Nuclear Regulatory Commission

11555 Rockville Pike

Mail Stop CS-05-C07M

Rockville, MD 20852

Reister, Richard

U.S. Department of Energy

NE-31 / Germantown Building

1000 Independence Avenue, SW

Washington, DC 20585-1290

Rusaw, Richard

Electric Power Research Institute

1300 West WT Harris Blvd.

Charlotte, NC 28262-7097
No. of

Copies

Tawfik, Magdy S.

Idaho National Laboratory

PO Box 1625, Mail Stop 3605

Idaho Falls, ID 83415-3605

Tilley, Richard

Electric Power Research Institute

1300 W WT Harris Blvd,

Charlotte, NC 28262

Usrey, Michael

Sporian Microsystems, Inc.

515 Courtney Way, Suite B

Lafayette, CO 80026-8821

Young, Garry G.

Entergy Nuclear

1340 Echelon Parkway

Jackson, MS 39213

\section{Foreign Distribution}

Behravesh, Mohamad M.

Electric Power Research Institute and the Materials Ageing Institute

MAI EDF R\&D, Site des Renardieres, 77818

Moret-sur-Loing Cedex, FRANCE

Bezdikian, Georges

Georges Bezdikian Consulting Co.

13 Avenue Marceau, 78110 LE

Vesunet, FRANCE

Bieth, Michel

Joint Research Centre

European Commission

P.O. Box 2, NL-1755 ZG

Petten, THE NETHERLANDS

Blahoianu, Andrei

Canadian Nuclear Safety Commission

P.O. Box 1046, Station B

280 Slater Street

Ottawa, Ontario, CANADA, K1P 5S9

Distr.1 
No. of

Copies

Brumovsky, Milan

Nuclear Research Institute Rez plc

Vltavska 130, Rez

CZECH REPUBLIC

Changugui, Jang

KAIST

291 Daehak-ro, Yuseng-yu

Daejeon, KOREA

Dobmann, Gerd

Fraunhofer-Institute IZFP

Campus E31, 66123

Saarbrucken, GERMANY

Han, En-Hou

Institute of Metal Research

Chinese Academy of Sciences

62 Wencui Road, Shenyang

Liaoning 110016, CHINA

Herter, Karl-Heinz

MPA University Stuttgart

Pfaffenwaldring 32, 70569

Stuttgart, GERMANY

Huang, Jiunn-Yuan

Institute of Nuclear Energy Research

PO Box 3-14, 1000 Wenhua Rd.,

Chiaan Village

Lung-Tan, Taoyuan, 325, TAIWAN

Huerta, Alejandro

Nuclear Energy Agency

Le Seine St-Germain, 12, boulevard des Iles, 92130

Issy-les-Moulineaux, FRANCE

Hwang, II Soon

Seoul National University

Bldg. 31-1, Dept. Nuc. Eng.

Seoul National University

1 Gwanak-ro, Gwanak-gu

Seoul, REPUBLIC OF KOREA
No. of

\section{Copies}

Hwang, Seong Sik

Korea Atomic Energy Research Institute

1045 Daedeokdaero, Yuseong

Daejeon, KOREA 305-353

Jeong, Yong Hwan

Korea Atomic Energy Research Institute

1045 Daedeokdaero, Yuseong

Daejeon, KOREA 305-353

Kain, Vivekanand

Homi Bhabha National Institute

Corrosion Science Section

Mumbai Head, INDIA

Kang, Ki Sig

International Atomic Energy Agency

Wagramer Strass 1400

Wien, AUSTRIA

Kang, Sung-sik

Korea Institute of Nuclear Safety

62 Gwahak-ro, Yuseong

Daejeon 305-338, KOREA

Karlsen, Wade

VTT Technical Research Centre of Finland

P.O. Box 1000, 02044

VTT, FINLAND

Lee, Bong Sang

Korea Atomic Energy Research Institute

1045 Daedeokdaero, Yuseong

Daejeon, KOREA 305-353

van der Lee, Jan

EDF, Materials Ageing Institute

EDF R\&D Site des Renardieres, 77818

Moret-sur-Loing Cedex, FRANCE

Martin, Oliver

European Commission, Joint Research

Centre - Institute for Energy

Westerduinweg 3, NL-1755LE

Petten, THE NETHERLANDS 
No. of

Copies

Miura, Yasufumi

Central Research Institute of Electric Power

Industry

2-6-1 Nagasaka, Yokosuka-shi

Kanagawa-ken 240-0196, JAPAN

Prunier, Valery

EDF, Representing NULIFE

1 Rue Saint-Louis, 77300

Fontainebleau, FRANCE

Rintamaa, Rauno

NULIFE

Vuorimiehentie 3, P.O. Box 1000, FI-0

Espoo, FINLAND

Ruscak, Martin

Research Centre Rez plc

Vltavska 130, Rez

CZECH REPUBLIC

Sakakibara, Yohei

IHI Corporation

1, Shin-nakahara cho, Isogo ku, Yokohamashi, Kanagawa-ken, JAPAN

Sakamoto, Kazunobu

Japan Nuclear Energy Safety Organization

3-17-1, Toranomon

Minato, Tokyo, 105-0001, JAPAN

Shoji, Tetsuo

Nuclear and Industrial Safety Agency \&

Tohoku University

6-6-10-302, Aramaki Aoba, Aoba-ku

Sendai 9808579, Miyagi, JAPAN
No. of

\section{Copies}

Stjarnsater, Johan

Studsvik Nuclear

SE-611 82 Nykoping, SWEDEN

Watanabe, Yutaka

Tohoku University

6-6-01-2 Aoba, Aramaki, Aoba-ku

Sendai, 980-8579 JAPAN

Yeh, Tsung-Kuang

National Tsing Hua University

No. 101, Section 2, Kuang-Fu Road

Hsinchu, Taiwan 30013

REPUBLIC OF CHINA

Yonezawa, Toshio

FRRI - Tohoku University

6-6-01, Aoba, Aramaki, Aoba-ku

Sendai 980-8579, JAPAN

Yoon, Jae Young

Seoul National University

Bldg. 31-1, Dept. Nuc. Eng.

Seoul National University

1 Gwanak-ro, Gwanak-gu

Seoul, REPUBLIC OF KOREA

26 Local Distribution

Pacific Northwest National Laboratory

LJ Bond

K5-26

DL Brenchley (25)

K6-50

Information Release 






Proudly Operated by Battelle Since 1965

902 Battelle Boulevard

P.O. Box 999

Richland, WA 99352

1-888-375-PNNL (7665)

www.pnl.gov 